\title{
PENGARUH KNOWLEDGE LEADERSHIP, KOMUNIKASI, DAN MOTIVASI TERHADAP KINERJA KARYAWAN PADA PT VALADOO INDONESIA
}

\author{
Rakhmawati Oktavianna \\ Fakultas Ekonomi Universitas Pamulang \\ Email: r.oktavianna21@gmail.com
}

\author{
ARTICLE INFO \\ Article History: \\ Received 22 May 2018 \\ Revised 15 June 2018 \\ Accepted 15 July 2018 \\ JEL Classification: \\ E24, J80, J81 \\ Keywords: \\ Leadership, \\ Communication, \\ Motivation, and \\ Performance of Employee
}

\begin{abstract}
Employee performance is considered important for organizations due to the success of an organization influenced by it. Job performance or achievement is the job result which accomplished by an employee in performing tasks according to the responsibility given to him. A common problem that must be considered in the company is related with job performance. Without good employee's performance at PT Valadoo Indonesia, its excellence is not going to happen. One of the factors that can be used to improve the employee's performance is knowledge leadership, communication and motivation. Leaders who have a good knowledge and experience will be able to improve the performance of employees in achieving the company's vision and mission. In carrying out the work, the employee can not be separated from communication with fellow co-workers, the boss and the subordinate. Good communication can be an appropriate means to improve employee performance. In addition to communication, it is also necessary if the motivation for employees with high work motivation usually has a peak performance. Therefore, the research aims to know what is the effect of knowledge of leadership, communication, and motivation on employee performance at PT Valadoo Indonesia either partially or simultaneously. The aim of the study is also to identify and analyze the effect of knowledge of leadership, communication, and motivation on PT Valadoo Indonesia employee performance. The theory used in this study is theories of human resource management, especially those related to knowledge leadership, communication, motivation, and performance of employees. Population used in this study is the employee of PT Valadoo Indonesia. Sampling technique used is simple random sampling. Method of data collection is using questionnaire data analysis that is Structural Equation Modeling (SEM) of Lisrel 8.7.
\end{abstract}

\section{PENDAHULUAN}

Pariwisata merupakan sumber devisa yang besar bagi suatu negara. Di Indonesia pun pariwisata berperan penting dalam menambah devisa negara. Indonesia yang memiliki kekayaan alam dan budaya merupakan 
komponen yang penting dalam perkembangan pariwisatanya. Untuk meningkatkan sektor pariwisata, pembangunan infrastruktur saja tidaklah cukup, hal lain yang mendukung peningkatan sektor pariwisata adalah kemudahan wisatawan dalam memperoleh informasi pariwisata di tempat yang sedang dikunjungi.

Jumlah wisatawan yang terus naik setiap bulannya, menjadikan peluang bisnis travel di Indonesia. Fenomena kinerja karyawan pada PT Valadoo Indonesia adalah karyawan kurang menjalankan pekerjaannya sesuai dengan prosedur dan target yang telah ditetapkan. Sehingga hal-hal yang menjadi keunggulannya tidaklah akan terwujud dengan baik.

Masalah umum yang harus diperhatikan pada perusahaan adalah masalah kinerja karyawan. Kinerja karyawan dianggap penting bagi organisasi karena keberhasilan suatu organisasi dipengaruhi oleh kinerja itu sendiri. Kinerja atau prestasi kerja adalah hasil kerja yang dicapai oleh seorang karyawan dalam melakukan tugas sesuai tanggung jawab yang diberikan kepadanya. Mangkunegara (2000) menyebutkan, faktor yang mempengaruhi kinerja adalah kemampuan (ability) dan faktor motivasi. Setiap organisasi maupun perusahaan akan berusaha untuk meningkatkan kinerja karyawan untuk mencapai tujuan organisasi yang telah ditetapkan. Berbagai cara ditempuh untuk meningkatkan kinerja karyawan misalnya melalui pendidikan dan pelatihan, pemberian kompensasi dan motivasi serta menciptakan lingkungan kerja yang baik. Dari sisi knowledge leadership, fenomenanya adalah pimpinan di PT Valadoo Indonesia berusia relatif muda dan kurang pengalaman sebagai seorang pimpinan. Hal ini terindikasi dari kurangnya kemampuan pimpinan memberi arahan pekerjaan kepada bawahan. Kemudian terlihat kurangnya pengetahuan pimpinan untuk mewujudkan visi dan misi perusahaan. Hal tersebut menjadikan kendala dalam mengembangkan perusahaan yang baru berjalan padahal pimpinan sangat berperan dalam perusahaan.

\section{TINJAUAN PUSTAKA}

\section{Knowledge Leadership}

Larson (2008) mendefinisikan knowledge leadership sebagai suatu informasi kunci untuk organisasi yang dengan pemahaman (pengetahuan) memungkinkan kelangsungan suksesnya misi organisasi, tidak terbatas pada ukuran atau kompleksitas. Sebaliknya, knowledge leadership lebih fleksibel dan adaptif sebagai pengetahuan baru yang dapat diasimilasi oleh anggota dan didistribusikan melalui budaya organisasi.

\section{Komunikasi}

Komunikasi merupakan salah satu aktivitas yang sangat fundamental dalam kehidupan umat manusia. Hal ini disebabkan karena keberadaan manusia sebagai makhluk sosial. Manusia tidak akan bisa hidup tanpa bantuan orang lain. Menurut Dr. Everett Kleinjen dari East Center Hawaii yang dikutip oleh Hafied Cangara (2007) menyatakan komunikasi sudah merupakan bagian kekal dari kehidupan manusia seperti halnya bernapas. Sepanjang manusia ingin hidup, maka ia perlu berkomunikasi. Dan sebagai makhluk individu, manusia selalu dihadapkan dengan berbagai kebutuhan dalam hidupnya. Untuk memenuhi kebutuhannya, maka manusia memerlukan bantuan orang lain. Dengan demikian, manusia akan berkomunikasi dengan manusia lainnya demi memenuhi kebutuhan tersebut sehingga sampai kapan pun, komunikasi merupakan hal yang tidak pernah akan lepas dari kehidupan manusia.

\section{Motivasi}

Mathis (2001) menjelaskan bahwa motivasi merupakan hasrat dalam seseorang yang menyebabkan orang tersebut melakukan tindakan untuk mencapai tujuan. Siagian (2002) mengemukakan dalam kehidupan berorganisasi, termasuk kehidupan berkarya dalam organisasi bisnis, aspek motivasi kerja mutlak mendapatkan perhatian serius dari para manajer karena empat pertimbangan utama yaitu: 
1. Filsafat hidup manusia berkisar pada prinsip "quit pro quo" yang dalam bahasa awam dicerminkan oleh pepatah yang mengatakan "ada ubi ada talas, ada budi ada balas".

2. Dinamika kebutuhan manusia sangat kompleks dan tidak hanya bersifat materi, akan tetapi juga bersifat psikologis.

3. Tidak ada titik jenuh dalam pemuasan kebutuhan manusia.
4. Perbedaan karakteristik individu dalam organisasi ataupun perusahaan, mengakibatkan tidak ada satupun teknik motivasi yang sama efektifnya untuk semua orang dalam organisasi juga untuk seseorang pada waktu dan kondisi yang berbeda-beda.

\section{Rerangka Pemikiran}

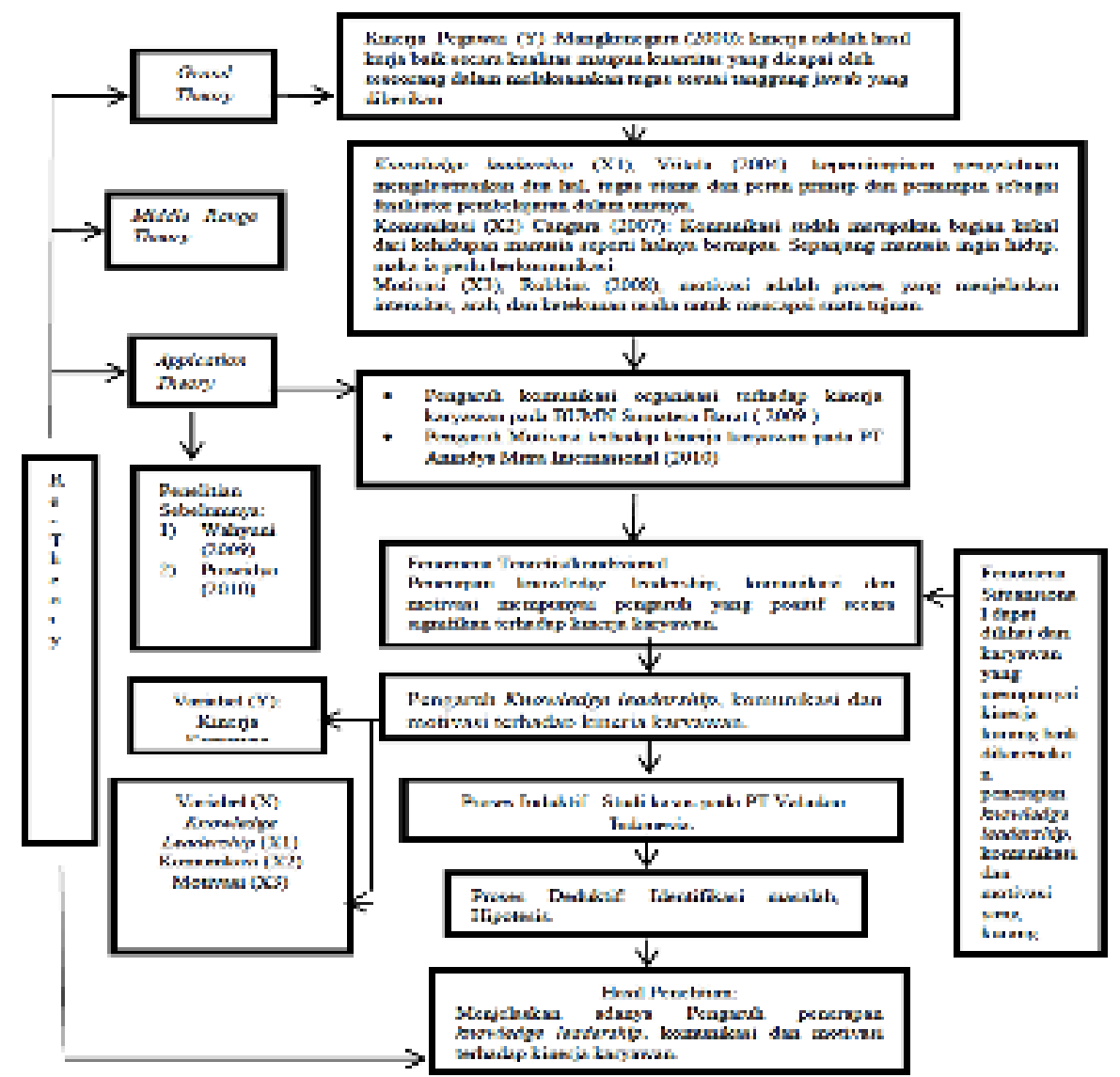

Gambar 1. Rerangka Pemikiran Teoretis

\section{Kinerja Karyawan}

Kinerja merupakan prestasi kerja, yakni perbandingan antara hasil kerja dengan standar kerja yang ditetapkan. Dengan demikian kinerja memfokuskan pada hasil kerjanya. Menurut Siagian (2002), kinerja adalah konsep yang bersifat universal yang merupakan efektivitas operasional suatu organisasi, bagian organisasi dan bagian karya berdasar standar dan kriteria yang ditetapkan. 
Menurut Mangkunegara (2000) kinerja adalah hasil kerja baik secara kualitas maupun kuantitas yang dicapai oleh seseorang dalam melaksanakan tugas sesuai tanggung jawab yang diberikan. Beberapa faktor yang berperan dalam kinerja antara lain adanya efektivitas keseimbangan antara pekerja dan lingkungan yang berada di dekatnya yang meliputi individu, sumber daya, kejelasan kerja dan umpan balik.

\section{Pengembangan Hipotesis}

Pengaruh Knowledge Leadership terhadap Kinerja Karyawan

Lazimnya, kepemimpinan muncul di antara orang dan organisasi. Chang dan Lee (2007), secara sederhana, menyatakan kepemimpinan adalah kemampuan untuk mempengaruhi orang lain. Bohn dan Grafton (dalam Chang dan Lee, 2007) menyatakan bahwa kepemimpinan berarti sebuah jalan untuk menciptakan visi yang jernih, memilih anak buah yang memiliki rasa percaya diri, yang diciptakan melalui koordinasi dan komunikasi.

Selain itu, knowledge leadership selalu berusaha mendengar masukan dengan penuh perhatian dan mendorong munculnya pandangan-pandangan dari sudut yang berbeda. Tentu untuk itu mereka harus menyediakan waktu dan sumber daya yang cukup untuk mengidentifikasi masalah dan tantangan yang dihadapi organisasi serta untuk melakukan refleksi dan penyempurnaan kinerja masa lalu organisasi. Oleh karena itu hipotesis yang diajukan dalam penelitian ini adalah:

H1: Knowledge leadership mempunyai pengaruh terhadap kinerja karyawan.

\section{Pengaruh Komunikasi terhadap Kinerja Karyawan}

Komunikasi yang dimaksud dalam penelitian di sini adalah komunikasi yang terjadi dalam dan antar bagian dalam organisasi. Komunikasi yang demikian ini dapat diharapkan akan dapat mempengaruhi kinerja dari anggota organisasi, sebenarnya tujuan yang mendasar dari komunikasi semacam ini adalah untuk mengkoordinasikan orang-orang dan bagian-bagian dalam organisasi sehingga hal-hal yang menjadi tujuan dari organisasi dapat tercapai. Dari kondisi ini dapat dirumuskan hipotesis dua sebagai berikut:

H2: Komunikasi mempunyai pengaruh terhadap kinerja karyawan.

\section{Pengaruh Motivasi terhadap Kinerja Karyawan}

Bagi seorang karyawan yang bekerja di dalam organisasi, motivasinya untuk mencapai tujuan organisasi akan membuatnya bersemangat untuk melaksanakan pekerjaannya. Jika karyawan bersemangat dalam bekerja, maka kinerjanya akan meningkat. Selain itu akan terbentuk komitmen karyawan untuk mencapai kinerja yang telah ditetapkan. Berdasarkan uraian tersebut, dapat diketahui bahwa motivasi yang dimiliki karyawan mempunyai pengaruh yang positif terhadap kinerja karyawan (Sunarcaya, 2008). Sehingga hipotesis ketiga dirumuskan sebagai berikut:

H3: Motivasi mempunyai pengaruh terhadap kinerja karyawan

\section{METODE PENELITIAN}

Desain Penelitian

Desain penelitian ini menggunakan pendekatan kuantitatif atau analisis data statistik. Desain penelitian merupakan rincian prosedur dalam memperoleh informasi yang diperlukan untuk memecahkan masalah masalah riset sumber daya manusia.

\section{Operasionalisasi Variabel Penelitian}

Menurut Wijanto (2008) dalam Structural Equation Modelling variabel dibedakan menjadi dua, yaitu:

1. Variabel laten

Merupakan konsep abstrak yang hanya diamati secara tidak langsung dan tidak sempurna melalui efeknya pada variabel teramati. Variabel laten terdiri dari dua jenis yaitu variabel eksogen dan endogen. 
2. Variabel teramati

Merupakan variabel yang dapat diamati atau dapat diukur secara empiris dan sering disebut sebagai indikator. Variabel teramati merupakan efek atau ukuran dari variabel laten.

\section{Jenis dan Sumber Data Penelitian}

Jenis data yang digunakan dalam penelitian ini adalah data subyek. Sebab tujuan penelitian ini adalah meneliti persepsi subyek karyawan mengenai knowledge leadership, komunikasi serta motivasi yang ada di PT Valadoo Indonesia, dan pengaruhnya terhadap kinerja karyawan. Sedangkan sumber data yang digunakan dalam penelitian adalah data primer. Dalam penelitian ini data diperoleh secara langsung dari responden dengan cara membagikan kuesioner/daftar pernyataan pada responden.

\section{Metode Pengumpulan Data}

Kuesioner berisikan sejumlah item pernyataan tertulis, yaitu responden diminta untuk memberikan tanggapan sesuai dengan persepsi mereka tentang item-item yang berkaitan dengan knowledge leadership, komunikasi, motivasi dan kinerja karyawan. Untuk mengkuantitatifkan data yang diperoleh dari responden yang bersifat kualitatif, maka diperlukan skala Likert.

\section{Populasi dan Sampel}

Populasi merupakan obyek atau subyek yang berada pada suatu wilayah dan memenuhi syarat tertentu yang berkaitan dengan masalah dalam penelitian maka yang menjadi populasi sasaran dalam penelitian ini adalah seluruh karyawan PT Valadoo Indonesia dan jumlah populasi yang ada kurang lebih 160 orang. Anggota sampel dipilih secara acak disebut dengan simple random sampling. Dalam penelitian ini, metode yang digunakan adalah teknik Structural Equation Modeling (SEM). Kemudian sampel yang digunakan sebanyak 150 sampel, berarti menggunakan aturan sampel 100-200: Maksimum Likelihood (ML).

\section{Metode Analisis}

Analisis yang digunakan dalam penelitian ini yaitu analisis kuantitatif. Dengan demikian penelitian ini menggunakan pengukuran yang dapat dihitung atau pengukuran yang melibatkan jumlah satuan tertentu atau dinyatakan dengan angka-angka. Analisis ini meliputi pengolahan data, pengorganisasian data dan penemuan hasil. Oleh karena itu pada penelitian ini, digunakan beberapa tahap yaitu, pada analisa awal pernyataan dalam kuesioner diuji terlebih dahulu untuk mengetahui adanya kuesioner yang valid ataupun tidak valid menggunakan SPSS 20. Lalu setelah setiap indikator atau instrumen pernyataan sudah memenuhi syarat validitas dan reliabilitas, baru bisa dilanjutkan menggunakan Lisrel 8.7.

\section{Analisis Awal}

Pada analisa awal pernyataan dalam kuisioner diuji terlebih dahulu untuk mengetahui adanya kuesioner yang valid ataupun tidak valid. Untuk uji validitas dan reliabilitas kuesioner menggunakan SPSS 20. Pada penelitian awal ini, kuesioner diuji terhadap 30 responden.

\section{Analisa Penelitian Struktural Equation Modelling (SEM)}

Tingkat pertama, yaitu Confirmatory Factor Analysis (CFA) merupakan model pengukuran yang menunjukkan suatu variabel laten diukur oleh satu atau lebih variabelvariabel teramati. Hal ini didasari alasan bahwa variabel-variabel teramati adalah indikatorindikator tidak sempurna dari variabel laten atau konstruk tertentu yang mendasarinya. Hasil CFA harus diperiksa terlebih dahulu dari kemungkinan terjadinya offending estimate (nilai koefisien estimasi dari model yang melampaui batas yang dapat diterima. 
Dalam pengujian SEM terdapat beberapa langkah yang harus ditempuh, antara lain (Wijanto, 2008):

1. Spesifikasi Model

Langkah ini merupakan langkah dalam melakukan identifikasi terhadap permasalahan penelitian, sehingga hubungan antar variabel-variabel yang dihipotesiskan harus didukung oleh teori yang kuat. Tahapan-tahapan untuk spesifikasi model ini meliputi: model pengukuran, pengembangan model pengukuran dalam SEM diwadahi dalam analisis faktor konfirmatori.

2. Identifikasi Model

Identifikasi langkah diperlukan dalam prosedur modeling persamaan struktural untuk memastikan bahwa model yang ditentukan bukan model bawah teridentifikasi atau unidentified. Diidentifikasi berdasarkan model model parameter adalah jumlah perkiraan lebih besar dari jumlah data yang dikenal.

3. Matriks input dan perkiraan parameter

Langkah ini dimaksudkan untuk memperoleh kinerja yang membentuk model matriks perkiraan setiap parameter ditentukan $\Sigma(\Theta)$ sehingga parameter value $S$ sedekat mungkin dengan nilai yang ada dalam matriks $S$ (kovarians matriks mengukur variabel). Dalam studi ini, estimasi model dilakukan dengan metode tradisional penggunaan kemungkinan maksimum (ML). Jika jumlah data yang diperoleh selama bertahun maka menggunakan metode kuadrat terkecil berbobot.

4. Pertandingan Uji
Tahapan uji coba dalam prosedur SEM dilakukan dengan mengevaluasi tingkat kompatibilitas antara data dan model. Hair et al. ( 2010) menyatakan bahwa evaluasi uji kesesuaian dilakukan melalui beberapa tingkatan, yaitu keseluruhan model fit.

5. Pengukuran Model Fit

Uji Kesesuaian dilakukan pada semua konstruksi terpisah melalui evaluasi validitas membangun dan mengevaluasi keandalan konstruk. Dalam kasus Analisis faktor konfirmatori digunakan sebagai model penelitian, jumlah variabel laten dan hubungan dengan satu laten variabel pengukuran variabel telah ditentukan terlebih dahulu. Ada tiga jenis tes yang dilakukan dalam analisis ini adalah Goodness of Fit, Uji Validitas dan Uji Reliabilitas.

\section{HASIL PENELITIAN DAN PEMBAHASAN}

Gambaran Umum Mengenai Objek Penelitian

PT Valadoo Indonesia mulai beroperasi

di akhir tahun 2010 sebagai digital startup dengan model daily deals. Pada pertengahan 2011 PT Valadoo Indonesia memfokuskan dirinya ke destinasi pariwisata di Indonesia sebagai jawaban dari kebutuhan masyarakat perkotaan di Indonesia yang seringkali kesulitan mencari pilihan untuk refreshing di tengah keseharian mereka.Valadoo memiliki visi untuk menjadi perusahaan parwisata berbasis digital terdepan yang menyediakan penawaran terbaik dan informasi terlengkap untuk destinasi liburan di Indonesia.

Hasil Confirmatory Factor Analysis (CFA) Uji Validitas dan Reliabilitas 


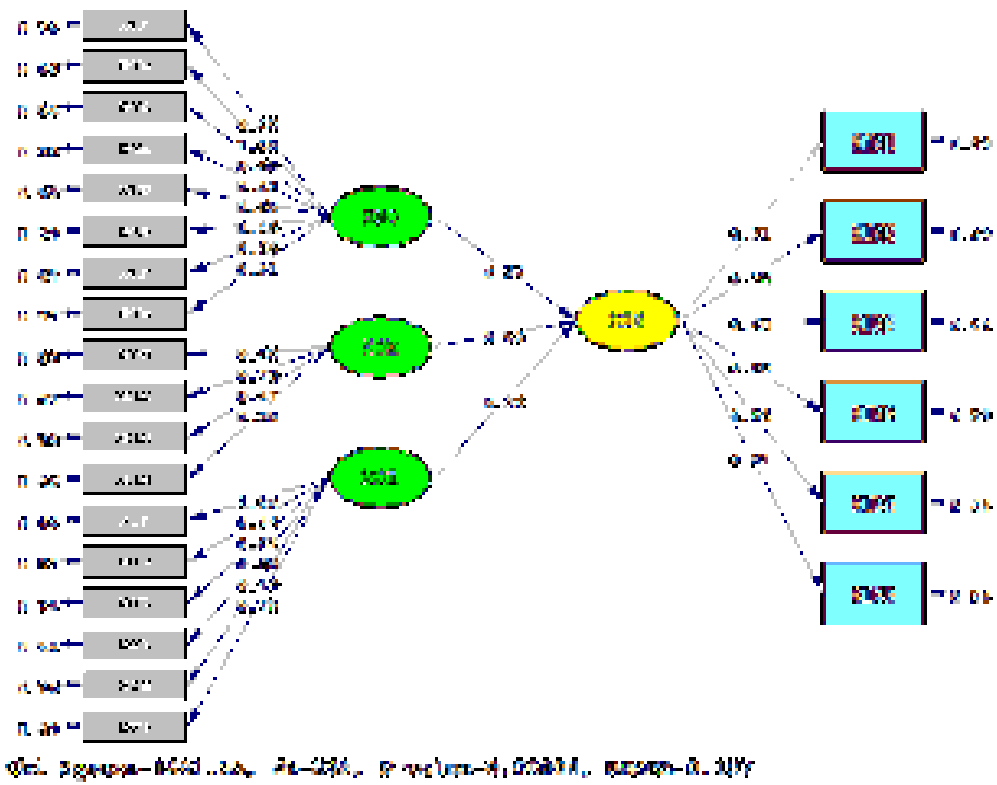

Gambar 2. CFA 1 - Basic Model Standardized Solution Pengaruh Knowledge Leadership, Komunikasi dan Motivasi terhadap Kinerja Karyawan

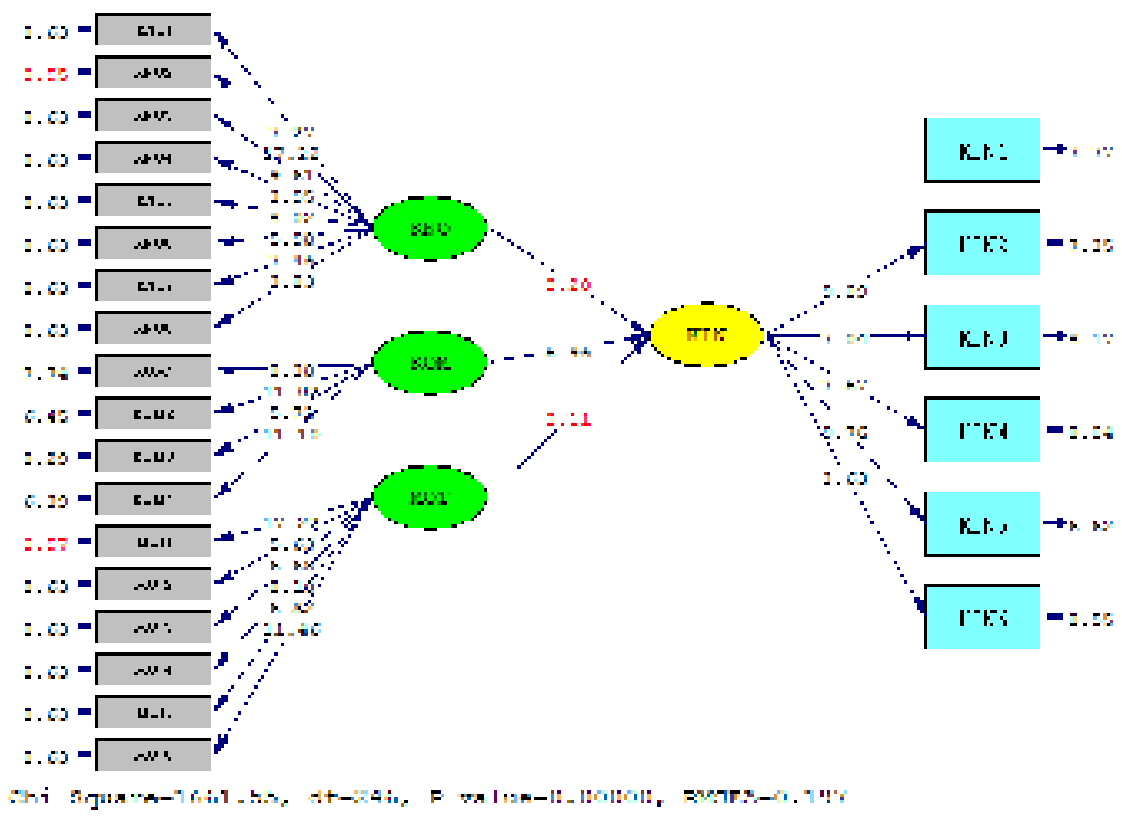

Gambar 3. CFA 1-Basic Model T-Values Knowledge Leadership, Komunikasi dan Motivasi terhadap Kinerja Karyawan 


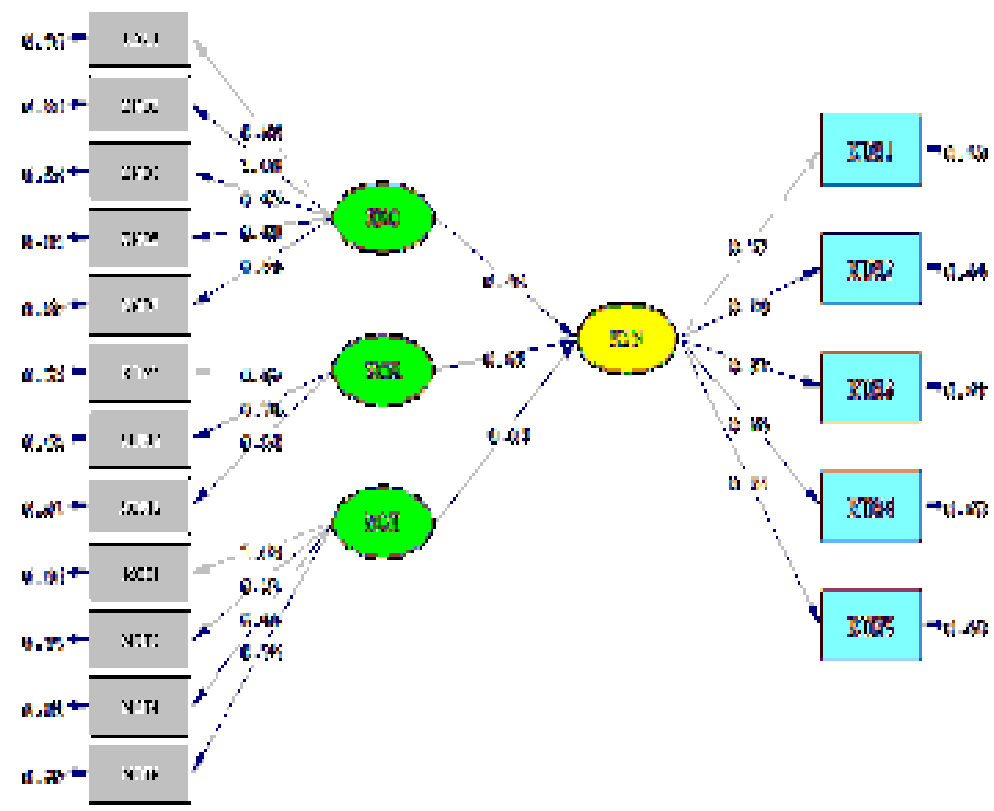

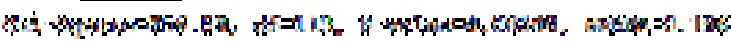

Gambar 4. CFA 2 - BasicModel Standardized Solution PengaruhKnowledge Leadership, Komunikasi dan Motivasi terhadap Kinerja Karyawan

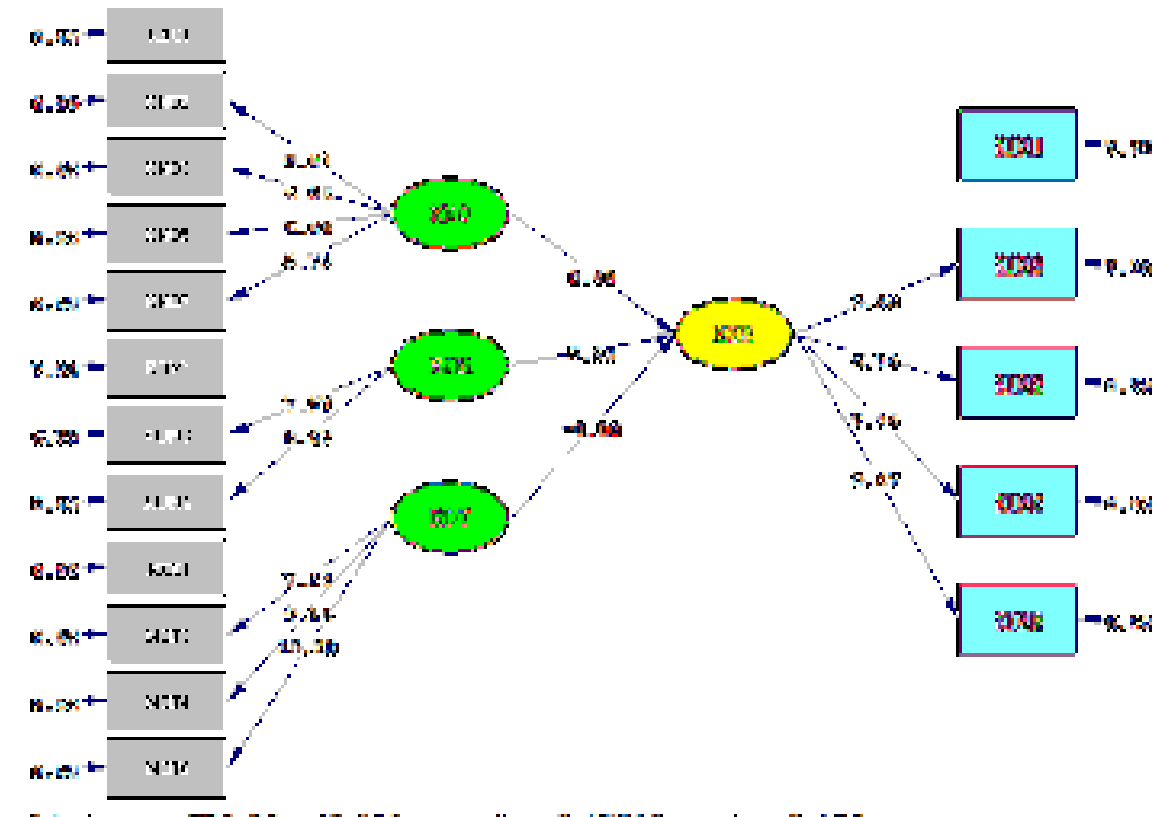

की

Gambar 5. CFA 2 -Basic Model T-Values Knowledge Leadership, Komunikasi dan Motivasi terhadap Kinerja Karyawan 
Uji Validitas dan Reliabilitas Kinerja Karyawan
Pengujian validitas dan reliabilitas pada variabel kinerja karyawan, ada pada Gambar 2 dan 3 yang dijelaskan pada tabel berikut:

Tabel 1. CFA 1 - Validitas dan Reliabilitas Kinerja Karyawan

\begin{tabular}{c|c|c|c|c|c|c|c}
\hline Indikator & $\begin{array}{c}\text { Standardized } \\
\text { Loading } \\
\text { Factors } \\
\text { (SLF) } \geq \mathbf{0 , 5}\end{array}$ & $\begin{array}{c}\text { Standard } \\
\text { Error }\end{array}$ & t-value & $\begin{array}{c}\text { Error } \\
\text { Variance }\end{array}$ & Ket. & $\begin{array}{c}\text { CR } \geq \\
\mathbf{0 , 7 0}\end{array}$ & $\begin{array}{c}\text { VE } \geq \\
\mathbf{0 , 5}\end{array}$ \\
\hline KIN1 & 0,71 & 0,49 & 0 & 0,29 & Valid & 0,91 & 0,63 \\
\hline KIN2 & 0,78 & 0,39 & 9,009 & 0,23 & Valid & & \\
\hline KIN3 & 0,6 & 0,64 & 7,04 & 0,3 & Valid & & \\
\hline KIN4 & 0,65 & 0,58 & 7,57 & 0,13 & Valid & & \\
\hline KIN5 & 0,84 & 0,3 & 9,56 & 0,18 & Valid & & \\
\hline KIN6 & 0,31 & 0,9 & 3,63 & 0,44 & Tidak Valid & & \\
\hline
\end{tabular}

Salah satu variabel teramati yaitu Kin6 tidak memenuhi persyaratan karena nilai standardized loading factor $<0,50$, walaupun $t$ value indikator Kin6 telah melebihi 1,96. Nilai standardized loading factor pada Kin6 hanya 0,31, karenanya variabel teramati tersebut dihapus karena dinilai kurang mewakili variabel kinerja.
Nilai Construct Reliability (CR) sebesar $0,91 \geq 0,70$ dan pada hasil Variance Extracted (VE) untuk variabel kinerja karyawan $0,63 \geq 0,50$ sehingga variabel kinerja karyawan memiliki konsistensi yang baik. Dikarenakan penghapusan variabel teramati pada Kin6, maka dilakukan pengolahan data kembali dengan CFA, dan hasilnya ada pada tabel berikut:

Tabel 2. CFA 2 - Validitas dan Reliabilitas Kinerja Karyawan

\begin{tabular}{c|c|c|c|c|c|c|c}
\hline Indikator & $\begin{array}{c}\text { Standardized } \\
\text { Loading } \\
\text { Factors } \\
\text { (SLF) } \geq \mathbf{0 , 5}\end{array}$ & $\begin{array}{c}\text { Standard } \\
\text { Error }\end{array}$ & t-value & $\begin{array}{c}\text { Error } \\
\text { Variance }\end{array}$ & Ket. & CR $\geq \mathbf{0 , 7 0}$ & VE $\geq \mathbf{0 , 5}$ \\
\cline { 4 - 7 } & 0,71 & 0,49 & 0 & 0,29 & Valid & 0,92 & 0,70 \\
\hline KIN1 & 0,78 & 0,39 & 9,009 & 0,23 & Valid & & \\
\hline KIN2 & 0,6 & 0,64 & 7,04 & 0,3 & Valid & & \\
\hline KIN4 & 0,65 & 0,58 & 7,57 & 0,13 & Valid & & \\
\hline KIN5 & 0,84 & 0,3 & 9,56 & 0,18 & Valid & & \\
\hline
\end{tabular}

Setelah variabel teramati Kin6 dihapus, hasil pengujian path diagram tersebut ada pada Gambar 4 dan 5. Hasil menunjukkan bahwa keseluruhan variabel teramati atas variabel laten kinerja karyawan telah memenuhi syarat validitas $\geq 0,5$ dan nilai $t$ - value $\geq 1,96$. Hasil dari Reliabilitas pun sudah baik, hal tersebut berarti reliabilitas pada variabel kinerja karyawan memiliki konsistensi yang baik. 


\section{Uji Validitas dan Reliabilitas Knowledge} Leadership

Pengujian validitas dan reliabilitas pada variabel knowledge leadership, ada pada
Gambar 2 dan 3 yang dijelaskan pada tabel berikut:

Tabel 3. CFA 1 - Validitas dan Reliabilitas Knowledge Leadership

\begin{tabular}{|c|c|c|c|c|c|c|c|}
\hline \multirow[b]{2}{*}{ Indikator } & \multirow{2}{*}{$\begin{array}{c}\text { Standardized } \\
\text { Loading } \\
\text { Factors } \\
(S L F) \geq 0,5\end{array}$} & \multirow{2}{*}{$\begin{array}{c}\text { Standard } \\
\text { Error }\end{array}$} & \multirow{2}{*}{$\begin{array}{c}t- \\
\text { value }\end{array}$} & \multirow{2}{*}{$\begin{array}{c}\text { Error } \\
\text { Variance }\end{array}$} & \multirow[b]{2}{*}{ Ket. } & \multicolumn{2}{|c|}{ Reliabilitas } \\
\hline & & & & & & $\begin{array}{c}C R \\
\geq 0,70\end{array}$ & VE $\geq 0,5$ \\
\hline KNO1 & 0,55 & 0,7 & 7,27 & 0,37 & Valid & \multirow[t]{8}{*}{0,88} & \multirow[t]{8}{*}{0,5} \\
\hline KNO2 & 1 & 0 & 17,22 & 0,0018 & Valid & & \\
\hline KNO3 & 0,69 & 0,53 & 9,61 & 0,26 & Valid & & \\
\hline KNO4 & 0,32 & 0,9 & 3,95 & 0,44 & Tidak Valid & & \\
\hline KNO5 & 0,6 & 0,64 & 8,02 & 0,43 & Valid & & \\
\hline KNO6 & 0,46 & 0,79 & 5,98 & 0,33 & Tidak Valid & & \\
\hline KNO7 & 0,56 & 0,69 & 7,46 & 0,48 & Valid & & \\
\hline KNO8 & 0,31 & 0,91 & 3,83 & 0,56 & Tidak Valid & & \\
\hline
\end{tabular}

Ada beberapa variabel teramati yaitu Kno4, Kno6 dan Kno8 tidak memenuhi persyaratan karena nilai standardized loading factor $<0,50$, walaupun $t$-value indikator Kno4, Kno6 dan Kno8 telah melebihi 1,96. Karenanya variabel teramati tersebut dihapus karena dinilai kurang mewakili variabel knowledge leadership. Pada uji reliabilitas variabel knowledge leadership menghasilkan nilai yang baik, dapat dilihat dari nilai Construct
Reliability (CR) sebesar $0,88 \geq 0,70$ dan pada hasil Variance Extracted (VE) untuk variabel knowledge leadership $0,5 \geq 0,50$ sehingga variabel knowledge leadership memiliki konsistensi yang baik. Dikarenakan penghapusan variabel teramati pada Kno4, Kno6 dan Kno8 maka dilakukan pengolahan data kembali dengan CFA, dan hasilnya ada pada tabel berikut:

Tabel 4. CFA 2 - Validitas dan Reliabilitas Knowledge Leadership

\begin{tabular}{|c|c|c|c|c|c|c|c|}
\hline \multirow[b]{2}{*}{ Indikator } & \multirow{2}{*}{$\begin{array}{c}\text { Standardized } \\
\text { Loading } \\
\text { Factors (SLF) } \geq \\
0,5 \\
\end{array}$} & \multirow[b]{2}{*}{$\begin{array}{c}\text { Standard } \\
\text { Error }\end{array}$} & \multirow[b]{2}{*}{$\begin{array}{c}\text { t- } \\
\text { value }\end{array}$} & \multirow[b]{2}{*}{$\begin{array}{c}\text { Error } \\
\text { Variance }\end{array}$} & \multirow[b]{2}{*}{ Ket. } & \multicolumn{2}{|c|}{ Reliabilitas } \\
\hline & & & & & & $C R \geq 0,70$ & VE $\geq 0,5$ \\
\hline KNO1 & 0,55 & 0,7 & 7,27 & 0,37 & Valid & \multirow[t]{5}{*}{0,88} & \multirow[t]{5}{*}{0,61} \\
\hline $\mathrm{KNO} 2$ & 1 & 0 & 17,22 & 0,0018 & Valid & & \\
\hline KNO3 & 0,69 & 0,53 & 9,61 & 0,26 & Valid & & \\
\hline KNO5 & 0,6 & 0,64 & 8,02 & 0,43 & Valid & & \\
\hline KNO7 & 0,56 & 0,69 & 7,46 & 0,48 & Valid & & \\
\hline
\end{tabular}

Setelah variabel teramati Kno4, Kno6 dan Kno8 dihapus, hasil path diagram menunjukkan bahwa keseluruhan variabel teramati atas variabel laten knowledge leadership telah memenuhi syarat validitas $\geq$
0,5 dan nilai $t$-value $\geq 1,96$. Hasil dari Reliabilitas pun sudah baik, hal tersebut berarti reliabilitas pada variabel knowledge leadership memiliki konsistensi yang baik. 
Uji Validitas dan Reliabilitas Komunikasi

Pengujian validitas dan reliabilitas pada variabel komunikasi, ada pada Gambar 2 dan 3 yang dijelaskan pada tabel berikut:

Tabel 5. CFA 1 - Validitas dan Reliabilitas Komunikasi

\begin{tabular}{|c|c|c|c|c|c|c|c|}
\hline \multirow[b]{2}{*}{ Indikator } & \multirow{2}{*}{$\begin{array}{c}\text { Standardized } \\
\text { Loading } \\
\text { Factors (SLF) } \\
\geq 0,5 \\
\end{array}$} & \multirow[b]{2}{*}{$\begin{array}{c}\text { Standard } \\
\text { Error }\end{array}$} & \multirow[b]{2}{*}{$t$-value } & \multirow[b]{2}{*}{$\begin{array}{c}\text { Error } \\
\text { Variance }\end{array}$} & \multirow[b]{2}{*}{ Ket. } & \multicolumn{2}{|c|}{ Reliabilitas } \\
\hline & & & & & & $\begin{array}{l}C R \geq \\
0,70\end{array}$ & $\begin{array}{l}\text { VE } \\
\geq 0,5\end{array}$ \\
\hline KOM1 & 0,65 & 0,58 & 8,38 & 0,28 & Valid & \multirow[t]{4}{*}{0,86} & \multirow[t]{4}{*}{0,61} \\
\hline KOM2 & 0,79 & 0,37 & 11,02 & 0,23 & Valid & & \\
\hline KOM3 & 0,47 & 0,78 & 5,72 & 0,45 & Tidak Valid & & \\
\hline KOM4 & 0,8 & 0,36 & 11,1 & 0,25 & Valid & & \\
\hline
\end{tabular}

Ada satu variabel teramati yaitu Kom3 tidak memenuhi persyaratan karena nilai standardized loading factor $<0,50$, walaupun tvalue indikator Kom3 telah melebihi 1,96. Nilai standardized loading factor pada Kom3 hanya 0,47 karenanya variabel teramati tersebut dihapus karena dinilai kurang mewakili variabel komunikasi. Nilai Construct Reliability (CR) sebesar $0,86 \geq 0,70$ dan pada hasil Variance Extracted (VE) untuk variabel komunikasi 0,61 $\geq 0,50$ sehingga variabel komunikasi memiliki konsistensi yang baik. Dikarenakan penghapusan variabel teramati pada Kom3 maka dilakukan pengolahan data kembali dengan CFA, dan hasilnya ada pada tabel berikut:

Tabel 6. CFA 2 - Validitas dan Reliabilitas Komunikasi

\begin{tabular}{|c|c|c|c|c|c|c|c|}
\hline \multirow[b]{2}{*}{ Indikator } & \multirow{2}{*}{$\begin{array}{l}\text { Standardized } \\
\text { Loading } \\
\text { Factors (SLF) } \\
\geq 0,5\end{array}$} & \multirow[b]{2}{*}{$\begin{array}{c}\text { Standard } \\
\text { Error }\end{array}$} & \multirow[b]{2}{*}{ t-value } & \multirow[b]{2}{*}{$\begin{array}{c}\text { Error } \\
\text { Variance }\end{array}$} & \multirow[b]{2}{*}{ Ket. } & \multicolumn{2}{|c|}{ Reliabilitas } \\
\hline & & & & & & $\begin{array}{l}C R \geq \\
0,70\end{array}$ & $\begin{array}{c}\text { VE } \\
\geq 0,5\end{array}$ \\
\hline KOM1 & 0,65 & 0,58 & 8,38 & 0,28 & Valid & \multirow[t]{3}{*}{0,87} & \multirow[t]{3}{*}{0,69} \\
\hline KOM2 & 0,79 & 0,37 & 11,02 & 0,23 & Valid & & \\
\hline KOM4 & 0,8 & 0,36 & 11,1 & 0,25 & Valid & & \\
\hline
\end{tabular}

Setelah variabel teramati Kom3 dihapus, hasil path diagram hasil pengujian menunjukkan bahwa keseluruhan variabel teramati atas variabel laten komunikasi telah memenuhi syarat validitas $\geq 0,5$ dan nilai $t$-value $\geq 1,96$. Hasil dari reliabilitas pun sudah baik, hal tersebut berarti reliabilitas pada variabel komunikasi memiliki konsistensi yang baik.

\section{Uji Validitas dan Reliabilitas Motivasi}

Pengujian validitas dan reliabilitas pada variabel motivasi, ada pada Gambar 2 dan 3 yang dijelaskan pada tabel berikut 
Tabel 7. CFA 1 - Validitas dan Reliabilitas Motivasi

\begin{tabular}{|c|c|c|c|c|c|c|c|}
\hline \multirow[b]{2}{*}{ Indikator } & \multirow{2}{*}{$\begin{array}{l}\text { Standardized } \\
\text { Loading } \\
\text { Factors } \\
(\mathrm{SLF}) \geq 0,5\end{array}$} & \multirow[b]{2}{*}{$\begin{array}{c}\text { Standard } \\
\text { Error }\end{array}$} & \multirow[b]{2}{*}{$\begin{array}{c}t- \\
\text { value }\end{array}$} & \multirow[b]{2}{*}{$\begin{array}{c}\text { Error } \\
\text { Variance }\end{array}$} & \multirow[b]{2}{*}{ Ket. } & \multicolumn{2}{|c|}{ Reliabilitas } \\
\hline & & & & & & $\begin{array}{c}C R \\
\geq 0,70\end{array}$ & $\begin{array}{l}\text { VE } \\
\geq 0,5\end{array}$ \\
\hline MOT1 & 1 & 0 & 17,22 & 0,0018 & Valid & \multirow[t]{6}{*}{0,9} & \multirow[t]{6}{*}{0,63} \\
\hline MOT2 & 0,44 & 0,81 & 5,63 & 0,26 & Tidak Valid & & \\
\hline МOT3 & 0,51 & 0,74 & 6,68 & 0,39 & Valid & & \\
\hline MOT4 & 0,6 & 0,64 & 8,1 & 0,28 & Valid & & \\
\hline MOT5 & 0,49 & 0,76 & 6,32 & 0,28 & Tidak Valid & & \\
\hline MOT6 & 0,78 & 0,39 & 11,46 & 0,32 & Valid & & \\
\hline
\end{tabular}

Ada dua variabel teramati yaitu Mot2 dan Mot5 tidak memenuhi persyaratan karena nilai standardized loading factor $<0,50$, walaupun t-value indikator Mot2 dan Mot5 telah melebihi 1,96. karenanya variabel teramati tersebut dihapus karena dinilai kurang mewakili variabel motivasi. Pada uji reliabilitas variabel komunikasi menghasilkan nilai yang baik, dapat dilihat dari nilai Construct
Reliability (CR) sebesar $0,9 \geq 0,70$ dan pada hasil Variance Extracted (VE) untuk variabel komunikasi $0,63 \geq 0,50$ sehingga variabel motivasi memiliki konsistensi yang baik.

Dikarenakan penghapusan variabel teramati pada Kom3 maka dilakukan pengolahan data kembali dengan CFA, dan hasilnya ada pada tabel berikut:

Tabel 8. CFA 2 - Validitas dan Reliabilitas Motivasi

\begin{tabular}{|c|c|c|c|c|c|c|c|}
\hline \multirow[b]{2}{*}{ Indikator } & \multirow{2}{*}{$\begin{array}{l}\text { Standardized } \\
\text { Loading } \\
\text { Factors } \\
\text { (SLF) } \geq 0,5 \\
\end{array}$} & \multirow[b]{2}{*}{$\begin{array}{c}\text { Standard } \\
\text { Error }\end{array}$} & \multirow[b]{2}{*}{$\begin{array}{c}t- \\
\text { value }\end{array}$} & \multirow[b]{2}{*}{$\begin{array}{c}\text { Error } \\
\text { Variance }\end{array}$} & \multirow[b]{2}{*}{ Ket. } & \multicolumn{2}{|c|}{ Reliabilitas } \\
\hline & & & & & & $\begin{array}{c}C R \\
\geq 0,70\end{array}$ & $\begin{array}{l}\text { VE } \\
\geq 0,5\end{array}$ \\
\hline MOT1 & 1 & 0 & 17,22 & 0,0018 & Valid & \multirow[t]{4}{*}{0,9} & \multirow[t]{4}{*}{0,63} \\
\hline МOT3 & 0,51 & 0,74 & 6,68 & 0,39 & Valid & & \\
\hline MOT4 & 0,6 & 0,64 & 8,1 & 0,28 & Valid & & \\
\hline МOT6 & 0,78 & 0,39 & 11,46 & 0,32 & Valid & & \\
\hline
\end{tabular}

Setelah variabel teramati Mot2 dan Mot5 dihapus, hasil path diagram hasil pengujian menunjukkan bahwa keseluruhan variabel teramati atas variabel laten motivasi telah memenuhi syarat validitas $\geq 0,5$ dan nilai t-value $\geq 1,96$. Hasil dari reliabilitas pun sudah baik, hal tersebut berarti reliabilitas pada variabel motivasi memiliki konsistensi yang baik.

\section{Uji Kecocokan Keseluruhan Model}

Pada penelitian ini menggunakan Structural Equation Modelling (SEM) yang terdapat dalam program Lisrel yaitu menguji bersama-sama model yang terdiri dari variabel independen dan variabel dependen. Menganalisa kecocokan data dengan model secara keseluruhan atau dalam Lisrel disebut Goodness-of-fitIndex (GFI). Pengujian ini akan mengevaluasi apakah model yang dihasilkan merupakan model fit atau tidak. Dari printed out yang dihasilkan estimasi pengukuran 2ndCFA pada Lisrel 8.7, analisa kecocokan keseluruhan model dapat dilihat dari angka pada tabel berikut: 
Tabel 9. Hasil Uji Kecocokan Model

\begin{tabular}{|c|c|c|c|c|}
\hline No. & $\begin{array}{c}\text { Ukuran Derajat } \\
\text { Kecocokan }\end{array}$ & Nilai & $\begin{array}{l}\text { Tingkat kecocokan } \\
\text { yang bisa diterima }\end{array}$ & Ket \\
\hline \multirow[t]{2}{*}{1} & Chi Square & 756 & \multirow[t]{2}{*}{$P$-value $>0,05$} & \multirow[t]{2}{*}{ Tidak Fit } \\
\hline & $\begin{array}{l}\text { Normed Chi Square } \\
\qquad(\times 2 / d f)\end{array}$ & $\begin{array}{c}P \text {-value }= \\
0,00\end{array}$ & & \\
\hline 2 & $\begin{array}{l}\text { Adjusted Goodness } \\
\text { of Fit Index (AGFI) }\end{array}$ & 0,49 & AGFI $>0,9$ & Tidak Fit \\
\hline 3 & $\begin{array}{c}\text { Root Mean Square } \\
\text { Error of } \\
\text { Approximation } \\
\text { (RMSEA) }\end{array}$ & 0,19 & $\begin{array}{c}\text { RMSEA } \leq 0,08 \text { (good } \\
\text { fit) }\end{array}$ & Tidak fit \\
\hline
\end{tabular}

Sumber: Hasil Pengolahan dengan LISREL 8.7

Nilai $P$ - value untuk Chi-Square $<0,05$ dan berdasarkan Goodness of Fit Indices (GFI)> 0,90 yang mengindikasikan bahwa model tidak fit, hal tersebut juga dapat dilihat dengan nilai RMSEA $<0,05$ dan AGFI 0,928. Nilai GFI dalam model regresi dianalogikan dengan $\mathrm{R}^{2}$. Tingkat penerimaan yang direkomendasikan adalah bila GFI dan AGFI mempunyai nilai yang sama atau lebih besar dari 0.90 Nilai RMSEA untuk model yang diteliti sebesar 0,19. Nilai RMSEA menunjukkan tidak fit yang dapat diharapkan bila model diestimasi dalam populasi. Dapat dikatakan model yang diperoleh dengan nilai RMSEA $=0,19$ tidak memiliki tingkat kecocokan (fit) dengan data sehingga dapat disimpulkan bahwa model penelitian tidak sesuai dengan kondisi empirik.

Berdasarkan ketiga kriteria di atas, model yang diperoleh tidak dapat digunakan untuk menjelaskan hubungan antar model yang diteliti. Artinya model yang diperoleh tidak dapat menjelaskan model pengaruh knowledge leadership, komunikasi dan motivasi terhadap kinerja karyawan. Dengan demikian hipotesis secara simultan yang menyatakan terdapat pengaruh signifikan knowledge leadeship, komunikasi dan motivasi terhadap kinerja karyawan tidak dapat diterima.

\section{Uji Kecocokan Model Struktural}

Setelah uji kecocokan keseluruhan model, maka tahap selanjutnya adalah menguji hipotesis penelitian pada model strukturalnya. Pengujian model ini dilakukan untuk mengetahui bagaiman hubungan antara variabel knowledge leadership, komunikasi dan motivasi terhadap kinerja karyawan. Dengan pengujian ini akan diketahui apakah hipotesis model penelitian diterima atau ditolak.

Keseluruhan variabel laten diukur dari 24 indikator/ variabel teramati yang telah disusun berupa pertanyaan. Hasil hipotesis diperoleh dari printed out hasil proses syntax dalam rumus persamaan olahan penelitian dan juga terdapat pada path diagram. Pada hubungan yang signifikan nilai t-value harus lebih besar daripada t-tabel. Hubungan yang tidak signifikan ditandai dengan nilai t-value berwarna merah pada path diagram dan hubungan yang signifikan pada path diagram nilainya $\geq 1,96$ ditandai dengan berwarna hitam.

Hasil yang digunakan adalah 2ndCFA ketika pengukuran model struktural lebih tepat dan akurat. Penelitian ini menggunakan tingkat kepercayaan 95\% dengan batas t-value 1,96. Berikut adalah path diagram hasil uji hipotesis model: 


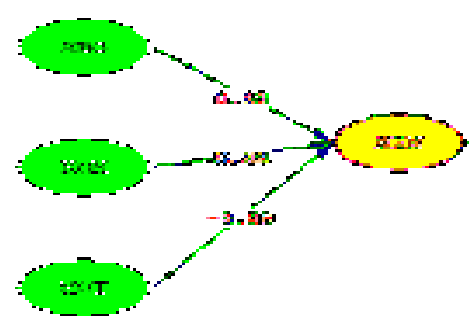

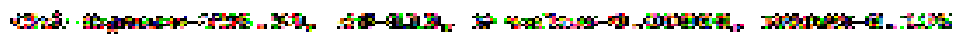

Gambar 6. Structural Model T-Values

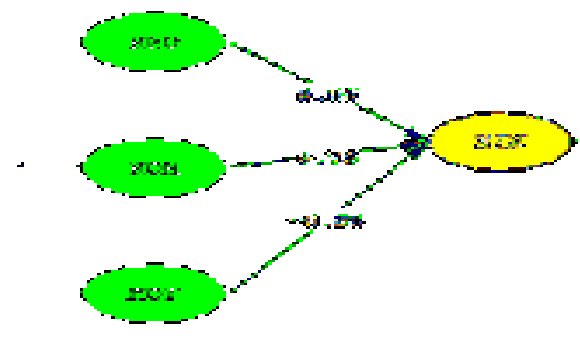

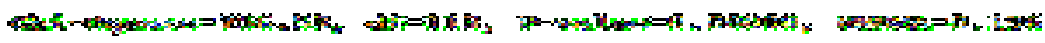

Gambar 7. Structural Model Estimates

\section{Analisa Kecocokan Model Struktural}

Pada tingkat kepercayaan 95\% atau error

$5 \%$, nilai t hitung yang diterima adalah sebesar
1,96. Hasil pengujian hipotesis pada penelitian ini dapat dilihat pada tabel berikut ini.

Tabel 10. Hasil Pengujian Hipotesis

\begin{tabular}{c|l|c|c|c}
\hline Hipotesis & \multicolumn{1}{|c|}{ Path } & t-value & Estimasi & Hasil \\
\hline H1 & $\begin{array}{l}\text { Leadership } \rightarrow \text { Kinerja } \\
\text { Karyawan }\end{array}$ & 0,43 & 0,66 & Ditolak \\
\hline H2 & $\begin{array}{l}\text { Komunikasi } \rightarrow \\
\text { Kinerja Karyawan }\end{array}$ & 5,33 & 0,75 & Diterima \\
\hline H3 & $\begin{array}{l}\text { Motivasi } \rightarrow \text { Kinerja } \\
\text { Karyawan }\end{array}$ & $-0,08$ & $-0,06$ & Ditolak \\
\hline
\end{tabular}


Berdasarkan gambar di atas maka diperoleh persamaan strukturalnya adalah sebagai berikut:

Persamaan dalam model di atas menunjukkan, variabel latet knowledge leadership memberikan pengaruh sebesar 0,66 atau dikuadratkan sebesar $\mathrm{R}^{2}=43,56 \%$ terhadap kinerja karyawan. Variabel laten komunikasi memberikan pengaruh sebesar 0,75 atau dikuadratkan sebesar $R^{2}=56,25 \%$ terhadap kinerja karyawan. Sedangkan variabel laten motivasi memberikan pengaruh sebesar 0,06 atau dikuadratkan sebesar $R^{2}=0,36 \%$ terhadap kinerja karyawan dan sisanya dipengaruhi oleh faktor lainnya.

\section{Hasil Hipotesis}

1. Pada uji hipotesis 1 yang menyatakan bahwa tidak ada pengaruh signifikan antara variabel knowledge leadership terhadap kinerja karyawan. Hasil pengujian hipotesis menunjukkan bahwa hipotesis ditolak atau
$\mathrm{KIN}=0.66 * \mathrm{KNO}+0.75 * \mathrm{KOM}-0.06 * \mathrm{MOT}+\mathrm{e}(1)$

tidak terbukti karena memiliki nilai t-value sebesar 0,43 lebih kecil dari 1,96.

2. Pada uji hipotesis 2 yang menyatakan bahwa ada pengaruh signifikan antara variabel komunikasi terhadap kinerja karayawan. Hasil pengujian hipotesis menunjukkan bahwa hipotesis diterima karena memiliki nilai t-value yang diperoleh sebesar 5,33 lebih besar dari 1,96.

3. Pada uji hipotesis 3 yang menyatakan bahwa tidak ada pengaruh signifikan antara variabel motivasi terhadap kinerja karyawan. Hasil pengujian hipotesis menunjukkan bahwa hipotesis ditolak karena memiliki nilai t hitung yang diperoleh sebesar -0,08 lebih kecil dari 1,96.

4. Pada uji hipotesis 4 yang menyatakan bahwa apakah ada pengaruh bersama-sama dari knowledge leadership, komunikasi dan motivasi terhadap kinerja karyawan dapat dilihat pada Tabel 11:

Tabel 11. Pengaruh Knowledge leadership, komunikasi dan motivasi terhadap kinerja karyawan

\begin{tabular}{l|c|c|c}
\hline \multicolumn{1}{c|}{ Model struktural } & $\mathbf{R}_{\text {square }}\left(\mathbf{R}^{2}\right)$ & $\mathbf{F}_{\text {hitung }}$ & Ket \\
\hline $\begin{array}{l}\text { Pengaruh knowledge leadership, } \\
\text { komunikasi dan motivasi terhadap } \\
\text { kinerja karyawan. }\end{array}$ & 0,485 & $49,69 *$ & $\mathrm{H}_{0}$ ditolak \\
\hline
\end{tabular}

*signifikan pada $\alpha=0,05$

Hasil pengujian memperlihatkan nilai $F_{\text {hitung }}>F_{\text {tabel }}(3,06)$ sehingga diketahui bahwa pengaruh variabel laten exogenous knowledge leadership, komunikasi dan motivasi terhadap variabel laten endogenous kinerja karyawan pada PT Valadoo Indonesia adalah signifikan, hal ini tercermin dari nilai koefisien determinasi sebesar $48,5 \%$, sehingga hipotesis keempat diterima. Jadi dapat disimpulkan hipotesis 4 yang menyatakan bahwa knowlegde leadership, komunikasi dan motivasi mempunyai pengaruh bersama-sama terhadap kinerja karyawan diterima atau terbukti.

\section{PENUTUP}

Simpulan

Berdasarkan hasil analisis terhadap knowledge leadership, komunikasi, motivasi dan kinerja karyawan yang dilakukan pada PT Valadoo Indonesia, maka diperoleh beberapa simpulan penelitian sebagai berikut:

1. Knowledge leadership mempunyai pengaruh terhadap kinerja karyawan, hal itu bermakna bahwa knowledge leadership meningkat akan menaikkan kinerja karyawan. Namun dari hipotesis untuk variabel knowledge leadership, dinilai tidak ada pengaruh signifikan antara variabel 
Rakhmawati Oktavianna: Pengaruh Knowledge Leadership...

knowledge leadership terhadap kinerja karyawan. Hal ini berarti bahwa hipotesis ditolak karena tidak terbukti. Pada PT Valadoo Indonesia terbukti bahwa pemimpin kurang memiliki kemampuan terhadap lingkungan eksternal dan internal perusahaan, kurang mampu memotivasi bawahannya untuk belajar hal-hal baru dan juga kurang dalam ketersediaan untuk mengajarkan para bawahan tentang pengetahuan kerja.

2. Komunikasi mempunyai pengaruh terhadap kinerja karyawan, hal itu bermakna bahwa komunikasi meningkat akan menaikkan kinerja karyawan. Dari hipotesis untuk variabel komunikasi, dinilai ada pengaruh signifikan antara variabel komunikasi terhadap kinerja karyawan. Hal ini berarti bahwa hipotesis dapat diterima karena terbukti. Pada PT Valadoo Indonesia terbukti bahwa kurangnya komunikasi antar rekan kerja atau sesama rekan kerja dalam masalah pekerjaan.

3. Motivasi mempunyai pengaruh terhadap kinerja karyawan, hal itu bermakna bahwa motivasi menurun akan menaikkan kinerja karyawan dan sebaliknya jika motivasi meningkat akan menurunkan kinerja karyawan. Dari hipotesis untuk variabel motivasi, dinilai tidak ada pengaruh signifikan antara variabel motivasi terhadap kinerja karyawan. Hal ini berarti bahwa hipotesis tidak dapat diterima karena tidak terbukti. Pada PT Valadoo Indonesia terbukti bahwa kurangnya pekerjaan yang menantang untuk karyawan dan ketidaksesuaian gaji yang diperoleh oleh karyawan.

4. Knowlegde leadership, komunikasi dan motivasi yang baik secara bersama-sama mempunyai pengaruh terhadap kinerja karyawan. Hal itu berarti jika knowldege leadership, komunikasi dan motivasi meningkat akan menaikkan kinerja karyawan. Sehingga dapat disimpulkan bahwa ketiga variabel tersebut harus bersama-sama berjalan dengan baik agar kinerja karyawan meningkat.

\section{Saran}

Berdasarkan hasil pembahasan dan simpulan penelitian maka diajukan beberapa saran sebagai berikut:

1. Bagi peneliti berikutnya dapat menguji secara lebih dalam mengenai variabelvariabel penelitian ini, sebab penelitian ini belum dapat menggambarkan secara keseluruhan mengenai variabel knowledge leadership, komunikasi, motivasi dan kinerja karyawan pada PT Valadoo Indonesia.

2. Bagi peneliti berikutnya dapat menguji dan menganalisis variabel yang ada pada perusahaan lain karena bisa saja hasil yang diperoleh berbeda. Dan juga diharapkan menambah indikator, menambah jumlah sampel dan mengganti ataupun menambahkan pernyataan dalam kuesioner yang lebih tepat untuk penelitian selanjutnya.

\section{DAFTAR PUSTAKA}

Antoni, F. (2006). Pengaruh Gaya Kepemimpinan Orientasi Tugas dan Orientasi Hubungan terhadap Motivasi Kerja dan Dampaknya pada Prestasi Kerja Pegawai Pengadilan Tinggi Tata Usaha Negara Surabaya. Tesis. Universitas 17 Agustus. Surabaya.

Behling, O. dan McFillen, Jaes M. (1996). A Syncretical Model of Charismatic/ Transformational Leadership, Group \& Organisational ManagementVol 21.

Cangara, H. (2007). Pengantar Ilmu Komunikasi. Jakarta: PT. Raja Grafindo Persada.

Chang, S. C., \& Lee, M. S. (2007). A study on relationship among leadership, organizational culture, the operation of learning organization and employees job satisfaction. The Learning Organization.

Dewi, Sutrisna. (2007). Komunikasi Bisnis. Edisi 1. Jakarta: C.V Andi Offset. 
Effendy, Onong U. (2005). IImu Komunikasi, Teori dan Praktek. Bandung: PT Remaja Rosdakarya.

Ferdinand, A. (2002). Structural Equation Modelling Dalam Peneltian Manajemen. Edisi 2, Seri Pustaka Kunci 03/BP UNDIP.

Greger, Kenneth R. dan Peterson, John S. (2000). Leadership Profiles for the New Millenium Cornell Hotel and Restaurant Administration Quaterly.

Hair, et al. (2006). Multivariate Data Analysis, 5th Edition, New Jersey: Prentice Hall International, Inc.

Brahmasari, Ida A. dan Suprayetno, Agus. (2008). Pengaruh Motivasi Kerja, Kepemimpinan dan Budaya Organisasi Terhadap Kepuasan Kerja Karyawan serta Dampaknya pada Kinerja Perusahaan (Studi kasus pada PT. Pei Hai International Wiratama Indonesia), Jurnal Manajemen dan Kewirausahaan, Vol 10.

Larson, W Donald. (2008). Knowledge Leadership. Tersedia di http://www.timeoutofmind.com/pdf/ke ynote/knowledge leadership.pdf

Luthans, F. (2006). Perilaku Organisasi. Yogyakarta: Penerbit Andi.

Mangkunegara, Anwar P. (2005). Evaluasi Kinerja SDM. Bandung: Refika Aditama.

(2000).

Manajemen Sumber Daya Manusia. Bandung: Penerbit Remaja Rosdakarya.

Masíud, F. (2004). Survai Diagnosis Organisasional Konsep \& Aplikasi. Semarang: Badan Penerbit Universitas Diponegoro.

Mathis, R. dan Jackson, J. (2001). Manajemen Sumber Daya Manusia. Terjemahan Jimmi Sadili dan Bayu. Jakarta: Salemba Empat.

Mulyana, D. (2005). Ilmu Komunikasi Suatu Pengantar. Bandung: Remaja Rosdakarya.
Robbins, Stephen P. (2003). Perilaku Organisasi Jilid 2. Jakarta: Indeks.

Robbins, Stephen P. dan Timothy A. Judge. (2008). Perilaku Organisasi Edisi ke-12. Jakarta: Salemba Empat.

Rosjidan. et al. (2001). Belajar dan Pembelajaran. Malang: Universitas Negeri Malang.

Siagian P. Sondang. (2002). Kiat Meningkatkan Produktivitas Kerja. Jakarta: Rineka Cipta.

Sardiman, A.M. (2007). Interaksi dan Motivasi Belajar Mengajar. Jakarta: PT Raja Grafindo Persada.

Silalahi, U. (2002). Pemahaman Praktis Asasasas Manajemen, Cetakan kedua. Bandung, Mandar Maju.

Sugiyono. (2010). Metode penelitian Kuantitatif Kualitatif dan R\&D. Bandung: Penerbit ALFABETA.

Sunarcaya, P. (2008). Analisa Faktor-faktor yang mempengaruhi Kinerja Pegawai diLingkungan Dinas Kesehatan Kabupaten Alor NTT. Jakarta: Universitas Terbuka.

Sumarsono, S. (2003). Ekonomi Manajemen Sumber Daya Manusia dan Ketenaga kerjaan. Jogyakarta: Graha IImu.

Solimun. (2002). Multivariate Analysis Structural Equation Modelling (SEM) Lisrel dan Amos. Malang: Fakultas MIPA Universitas Brawijaya.

Viitala, R. (2004). Towards knowledge leadership. Leadership \& Organization Development Journal, Vol. 25.

Wayne, R. Pace dan Don F. Faules. (2005). Komunikasi Organisasi. Bandung: PT Remaja Rosdakarya.

Wiryanto. (2004). Pengantar IImu Komunikasi. Jakarta: PT Grasindo. 
